\title{
OBITUARIES
}

For the full versions of articles in this section see bmj.com

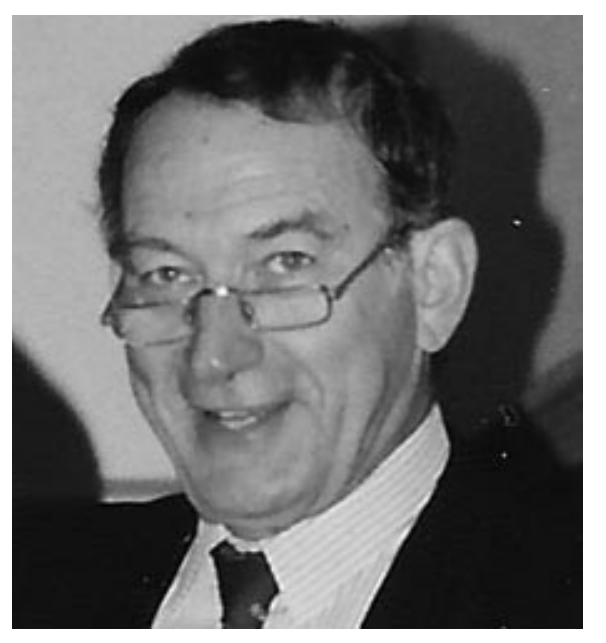

\section{Imre Joseph Pál Loefler}

\section{Surgeon, controversial writer, and polymath}

Imre Loefler was well versed in philosophy, history, ecology, and wildlife conservation, as well as medical education and surgery. In speeches and over 1000 articles and scientific papers he challenged the status quo in many different disciplines, his influence extending far from his home in Nairobi.

In 1944 Imre was enrolled in an army cadet school in Budapest and was soon captured by the German army and sent to the Polish war front. After six months he escaped to Germany, where the Americans captured him in May 1945. In the prisoner of war camp he helped in a clinic, performing his first operation, the incision of a buttock abscess.

On discharge from prison in Regensburg he worked in a US army hospital preparing histological slides. His parents found him through the Red Cross and took him back to school in Budapest, but he was refused entry to medical school by the communist government because of his "bourgeois" background. Within a month, he escaped from Hungary, on foot across the Austrian border, and returned to Regensburg. There he worked as a coal miner until he could afford to enrol in its medical school. He won the national scholarship, Die Studienstiftung des Deutschen Volkes, with free tuition, a salary, and the chance to study philosophy and history alongside medicine. Here he gained his grounding in philosophy at the feet of, among others, Erwin Schrodinger, Karl Popper, and Pablo Casals.

Reading British and American journals, Imre thought that German surgery had been left behind, mainly because of the way it was organised. He retrained in the United States. Inspired by the reputation of Makerere University in Uganda, he tried to arrange an African assignment but found that neither of his diplomas was recognised by the colonial government. In 1964, however, he gained work at a mission hospital in Uganda, maturing as a surgeon and acquiring his lifelong interest in wildlife.

In 1967 he was invited to join the department of surgery in Mulago, Uganda's teaching hospital, as a senior lecturer. And in 1970 he was appointed the foundation professor of surgery to Zambia's new medical school in Lusaka. Here Imre also learnt to fly and became an honorary game warden. His department of surgery was firmly based on the Mulago principles of service, teaching, and research. However, tensions and jealousies within the medical school resulted in his expulsion from the country in 1975 .

Imre was then invited to Nairobi Hospital and spent 31 years there until he retired in 2006 . He soon became a very busy surgeon but for many years would spend every Monday flying to remote hospitals to operate and teach. The Nairobi Hospital, a private institution, gave him few teaching opportunities, but he established the library and founded the Proceedings of Nairobi Hospital, which he edited for nine years.

As a council member of the Association of Surgeons of East Africa (ASEA), Imre was responsible for Zambia becoming the first additional member country in 1974 . Later, as chairman he played a large role in developing and monitoring surgical training throughout the region.

From 1998 to 2005 he was chairman of the East African Wildlife Society; he tried to give a new direction to conservation, believing that people would conserve wildlife only when they received direct benefits from so doing. His advocacy of consumptive utilisation of wildlife threw him into conflict with the many nongovernmental organisations concerned with animal welfare.

Imre had a weekly column in the East African Standard, which was usually polemical and disturbing, engaging always with topics affecting his fellow Kenyans (he had acquired Kenyan citizenship in the '80s) such as governmental inefficiency and corruption, deforestation, land erosion, the declining water supply. $\mathrm{He}$ crossed swords with the Catholic Church for its views on abortion, birth control, and AIDS and weighed frequently into Africa's root cause for its underdevelopmentnamely, its burgeoning birth rates. In his popular Soundings column for the $B M J$ he consistently stuck to his editor's brief-to be as splenetic as possible. His essay was the first winner of the Wakley prize, established by the Lancet in honour of its founder. He produced many book reviews; those of surgery were always from the viewpoint of a surgeon working in a poor environment and one who believed all surgical practice should be based on the basic principles underlying wound healing, management of infection, and repair of tissues. He decried the advent of the superspecialist and of new procedures that depended on technically complex techniques that were not attainable, or appropriate, outside of the metropolitan hospitals of the West.

He was invited to lecture throughout Africa, Europe, the US, and Australia. In 2005, in recognition of his speaking and writing, the Satima Foundation was established in Kenya to promote essay writing and rhetoric among Kenyans.

Prostate cancer was diagnosed in 2000. He faced his fate with the rational view of the agnostic he was, continuing to work, fly, write, and travel extensively almost to the end. He leaves a wife, Martha, and four children.

John Craven, John Jellis, Francis Omaswa Imre Loefler, former surgeon in private clinical practice Nairobi (b 1929; q Regensburg, Germany, 1954; FRCS Ed), d 11 March 2007. 


\section{Florence Claire Ruth Brown (née Richardson)}

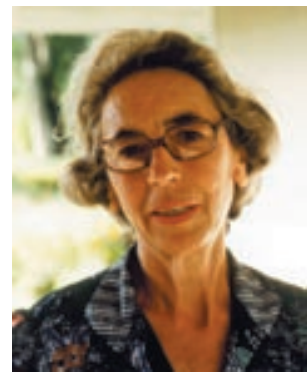

Former thoracic surgeon United Kingdom and anaesthetist New Zealand (b 1915; q Royal Free Hospital, London, 1941; FRCSEd), d 22 August 2006.

After qualifying, Ruth Richardson was unable to return to her native Jersey, and her request to join the war effort was declined. She therefore pursued her interest in surgery, eventually becoming senior surgical registrar in thoracic surgery at Hill Top Hospital, Bromsgrove. Marriage to a Nottinghamshire general practitioner, Bob Brown, in 1952 prompted her move to Nottingham City Hospital. In 1967 they emigrated to New Zealand, where Ruth took up anaesthetics at the Memorial Hospital in Hastings until 1977, when she and Bob did voluntary medical work for two years in Papua New Guinea. They retired to the South Island of New Zealand, Ruth remaining active in community work. Predeceased by Bob in 1994, she leaves two sons and five grandchildren.

Hugh Brown

\section{Jack Philip Lask}

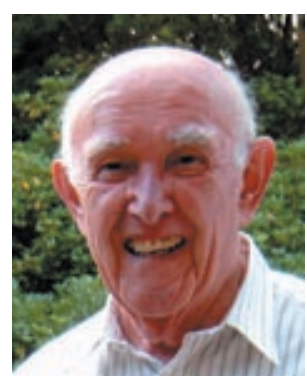

Former general practitioner Ascot and Bracknell, Berkshire (b 1916; q Leeds 1940), died from bronchopneumonia on 31 March 2007.

Jack Lask joined the Royal Army

Medical Corps in 1940, serving in
India, Persia, Iraq, Egypt, Sicily, Italy, and Greece. After the war he joined a singlehanded practice in Ascot, taking over when his partner retired. In 1952 he moved into one of the first housing estates to be constructed in the new town of Bracknell, where he built a house and another surgery. The size of his practice increased with the growth of the town to become a partnership of six doctors. For many years Jack was the doctor at Ascot Races. He also had a large midwifery practice and served on the local medical committee. Jack retired in 1985. He leaves a wife, Clarice; two daughters; and five grandchildren. Judy Trewin

\section{Kathleen Joyce McCarthy (née Evers)}

Former school medical officer London County Council (b 1912; q University College Hospital 1937), died from dementia on 2 January 2007. Head girl at her boarding school and captain of hockey, Joyce was academic, athletic, and passionate. At school and medical school she expressed her feelings on life, love, loss of faith, and even the dissection room, through poetry. In 1945 with fouryoung children she was doctor to LCC (London County Council) school and baby clinics. In the early 1960 s she and her husband, John, retired to Butlerstown, County Cork, for 10 years. After John's death in 1975 , Joyce moved near to her daughter. Her loves at this time included her garden and china. She leaves three children and eight grandchildren. Fiona Subotsky

\section{Edmund Rainey}

Former consultant orthopaedic surgeon Pinderfields Hospital, Wakefield (b 1936; q Queen's University, Belfast, 1960; FRCSI, FRCS Ed), died from oesophageal cancer on 16 February 2007.

Edmund Rainey undertook specialist training in orthopaedic surgery at Musgrave Park Hospital, Belfast. In 1971 he was appointed consultant at Pinderfields Hospital, Wakefield, where he worked until his retirement in 1996. He was also a member of the founding committee of Methley Park Hospital, and served on the committee of the Wakefield and District Mobile Physiotherapy Association. He was an active member of Wakefield Round Table, becoming chairman in 1976. He leaves a wife, Rosemary; three children; and seven grandchildren. Joe Tosh

\section{Charles James Crawford Renton}

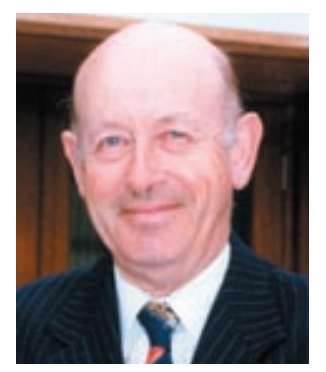

Former general surgeon Hereford County Hospital (b 1930; q Glasgow 1953; FRCS), d 9 February 2007. Charles Renton trained as a general surgeon in Glasgow, Nottingham, and Sheffield after his early career was interrupted by national service and the Suez crisis. In 1969 he was appointed consultant general surgeon with an interest in vascular and breast surgery in Hereford, where he remained until his retirement in 1995 . He was president of the Herefordshire Medical Society and the local branch of the BMA, as well as being involved in local hospital management. On his retirement the Charles Renton Oncology Unit was opened at the hospital. In retirement Charles wrote a book on the history of the Herefordshire Hospitals and another on the history of Hampton Park United Reformed Church. He leaves a wife, Margaret; four daughters; and six grandchildren.

Morag Renton

\section{Ethel Valerie Slater}

Former general practitioner Preston (b 1936; q Liverpool 1961; MRCGP), died from malignancy on 1 August 2006. Ethel turned down an interview to read history at Oxford to study medicine at Liverpool. She initially trained as a pathologist at Preston Royal Infirmary before joining her husband in the family general practice in 1966. In the 1970 s she began a lifelong involvement in the teaching and training of medical students and general practitioners. She was instrumental in setting up local workshops for the royal college to prepare trainees for the MRCGP oral examinations. During the 1980s she helped provide community cytology clinics. Retiring from general practice in 1996, Ethel worked for the Appeals Service until just a few months before her death. She leaves a husband, Alan; three daughters; and eight grandchildren.

Angela Robb, Sarah Slater, Catherine Steventon

\section{Oliver Smith}

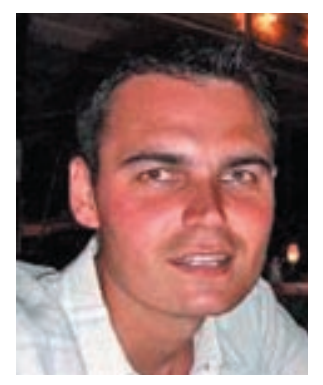

Senior house officer in surgery and teaching fellow to Imperial College students Northwick Park Hospital (b 1978, University College London 2001; MRCS), died from colon cancer on 29 March 2007.

From 2004 to 2006 Oliver Smith did surgical training at Northwick Park and St Mark's Hospitals, where he completed his MRCS examinations and published research on restorative proctocolectomy for Crohn's disease. During his senior house officer rotation Oliver flourished as a teacher. He became an ALS (advanced life support) instructor and then teaching fellow to Imperial College students. His warm and engaging style led to him being nominated by over 30 students for the 2007 NHS teaching award. He also set up a course for A level students to learn about careers in medicine. He leaves a fiancée and his parents.

Daniel Sado, Gillian Park 